\title{
Sociobiology
}

RESEARCH ARTICLE - BEES

\section{Diversity of flower visiting bees of Eugenia uniflora L. (Myrtaceae) in fragments of Atlantic Forest in South Brazil}

\author{
MER DINIZ, MLT BUSCHINI \\ Universidade Estadual do Centro-Oeste, Guarapuava-PR, Brazil
}

\section{Article History}

\section{Edited by}

Anne Zillikens, University of Tuebingen, Germany

Received

Initial acceptance

Final acceptance

Publication date

\section{Keywords}

Species richness, Halictinae, Anthrenoides paolae, Apis mellifera, Scaptotrigona bipunctata.

\section{Corresponding author}

Mary Ellen dos Reis Diniz

Universidade Estadual do Centro-Oeste

Departamento de Ciências Biológicas

Programa de Pós-Graduação em Biologia Evolutiva

Rua Simeão Camargo Varela de Sá, n. 3, Cascavel

CEP 85040-080 - Guarapuava, Paraná, Brasil

E-Mail: maryreisdiniz@yahoo.com.br

\begin{abstract}
Eugenia uniflora L. (Myrtaceae) is pollinated mostly by bees and there are no restrictions for pollen collection in their flowers. This stimulated us to study the bee diversity on its flowers in two forest fragments in southern Brazil, in August and September, 2012. A total of 826 bees belonging to 39 species and four subfamilies were captured with entomological nets. Halictinae presented the greatest richness, followed by Apinae, Colletinae and Andreninae. Apis mellifera was the only common species and the most abundant, followed by Scaptotrigona bipunctata and Melipona obscurior. Seven species were classified as intermediate and 31 as rare. Highest numbers of bees were collected from 10 to $11: 30 \mathrm{~h}$. The species richness of flower visiting bees was much higher than that of previous studies with first records of Plebeia remota and Anthrenoides paolae. Eugenia uniflora is a food source for exotic and native bees and possibly contributes to the conservation of these bees in forest fragments. In return, the bees probably act in maintaining this plant native of the Atlantic Forest.
\end{abstract}

\section{Introduction}

The Brazilian Atlantic Forest is one of the world's most diverse biomes, one of those most threatened by anthropic action (Myers et al., 2000), and one of 34 world hotspots and priority areas for conservation (Conservation International do Brasil et al., 2000). Within the Atlantic Forest biome the mixed ombrophilous forest formation (forest with Araucaria) is an area of great interest given its high biodiversity (Silveira et al., 2002).

Deforestation impacts, habitat fragmentation, exotic species introduction and irrational agriculture practices are the likely main causes of diminishing native populations of pollinators (Kevan \& Phillips, 2001; Kremen et al., 2002; Steffan-Dewenter et al., 2006). This can affect reproduction of native plants and eventually lead to local extinction of plant populations, as well as of the animals which depend on them
(Pinheiro Machado \& Silveira, 2006). In tropical areas the bees are considered the main pollinators (Ramirez \& Brito, 1992) and the animals best adapted to pollination (Faegri \& Pijl, 1979). Bees and other pollinators seem to be declining globally (Potts et al., 2010) and habitat loss appears to be the most important factor driving the decline of bees (Brown \& Paxton, 2009).

Myrtaceae is one of the largest plant families with thousands of species and approximately 140 genera, considered important in several Neotropical ecosystems (Johnson \& Briggs, 1984; Kawasaki \& Landrum, 1997; Wilson et al., 2001). It is one of the families most often found in the different vegetation formations of Brazil (Silva et al., 2001). Eugenia, a genus with approximately 1,000 species, is one of the largest genera, with distribution mostly in Central and South America (Merwe et al., 2004). In Brazil, Eugenia predominates with 388 species of which 302 are endemic (Sobral et al., 2015). 
Eugenia uniflora, known commonly as "Pitangueira", is a native species from mixed ombrophilous forest, and a tree that can be used in landscaping or cultivated in home orchards (Lorenzi, 2000; Lorenzi, 2002). It has monoecious and generalist flowers, and pollen grains as the only floral reward to pollinators. It is therefore classified as a "pollenflower", which is characteristic of many species in this genus (Romagnolo \& Souza, 2006). It has a prominent role in the natural regeneration of mixed ombrophilous forest, through seed replacement and by providing food for birds (Aguiar et al., 2013). Eugenia uniflora grows under different shading conditions, and propagates easily by seeds, these being the determining factors in the regeneration process (Scalon et al., 2001; Callegaro et al., 2012). Silva \& Pinheiro (2007) report that its flowers are visited by a wide variety of insects, including bees, which are the most common visitors.

During the anthesis period, which starts at the sunrise, remaining until the end of the day (Silva \& Pinheiro, 2007), the pollen grains are totally exposed, without any restrictions to collection, a common trait of generalist flowers (Faegri \& Pijl, 1979; Endress, 1994). The mass flowering, a common feature in Myrtaceae (Lughadha \& Proença, 1996), makes the flowers stand out and gives a white aspect to the plants that can be considered as a strategy to attract pollinators (Gentry, 1974; O’Brien \& Calder, 1993). The pollination in Myrtaceae is highly diversified and its species are visited by a large variety of animals, including bees, wasps, flies, birds and even mammals, but bees are the main pollinators (Beardsell et al., 1993; Proenca \& Gibbs, 1994; Lughadha \& Proença, 1996). In the Neotropical Region, the most common visitors of Myrtaceae are Apinae (Lughadha \& Proenca \& 1996). In a review on the flower visitors of Myrtaceae Gressler et al. (2006) reported bees the subfamilies Apinae and Halictinae only.

In the early hours of the morning, the flowers exhale a smooth and sweet odor (Silva \& Pinheiro, 2007), a strategy directly related to the attraction of bees (Faegri \& Pijl, 1979, Endress, 1994; Proença \& Gibbs 1994; Maués \& Couturier, 2002). Eugenia uniflora produces fruit after cross-pollination and self-fertilization (Franzon et al., 2011) however, self-fertilization in a natural population may result in inbreeding depression (Keller \& Waller, 2002), which reduces fertility, viability of the seeds, vigor, among others (Mettler \& Gregg, 1973; Falconer \& Mackay, 1996). According to Franzon et al. (2010) for the preservation of the E. uniflora is necessary to preserve them in the original forest fragments to ensure sufficient variability.

This study sought to document the diversity of the flower visiting bees of E. uniflora in fragments of mixed ombrophilous forest in south Brazil.

\section{Materials and methods}

\section{Research Area}

This research was conducted in two areas, located in the Guarapuava municipality, Paraná state $\left(25^{\circ} 23^{\prime} 36^{\prime \prime} \mathrm{S}\right.$; $51^{\circ} 27^{\prime} 19^{\prime \prime} \mathrm{W}$ ) in the central-south region of the state. According to the Köppen Geiger classification the climate in this region is humid subtropical, without a dry season, with the occurrence of severe frosts, average annual temperature around $22^{\circ} \mathrm{C}$ and average annual precipitation of $1961 \mathrm{~mm}$.

The two study areas are fragments of mixed ombrophilous forest with similar plant physiognomy. The areas are located around $25^{\circ} 22^{\prime} 05^{\prime \prime} \mathrm{S} / 51^{\circ} 32^{\prime} 27,16^{\prime \prime} \mathrm{W}$, with 8 ha, and $25^{\circ} 23^{\prime} 43^{\prime \prime} \mathrm{S} / 51^{\circ} 25^{\prime} 29^{\prime \prime} \mathrm{W}$, with $60 \mathrm{ha}$. The areas are $12 \mathrm{~km}$ distant from each other and are surrounded by other fragments of this same formation and crop fields.

\section{Sampling design}

The visits for the monitoring of flowering phenology and the collection of flower visitors were performed between the end of August and during September 2012. In total we selected 51 trees to monitor the flowering and to collect the bees. During the whole flowering period bees were captured on E. uniflora flowers daily. The collection days alternated between the two study areas.

In 30-minute intervals per hour, the bees that visited E. uniflora flowers were captured using entomological nets, by one collector. All collected individuals were sorted into morphospecies. Some specimens were sent for identification to Gabriel A. R. Melo, at Universidade Federal do Paraná (UFPR). The rest of the obtained specimens were deposited at the Entomological Collection of Bees and Wasps of the Biology and Ecology Laboratory, of Universidade Estadual do Centro-Oeste (UNICENTRO).

\section{Data analysis}

The indices of Shannon-Wiener, Margalef and Pielou were used to assess the diversity, richness and evenness of the bees. Those indices were obtained and calculated using the PAST ${ }^{\circledR}$ software (Paleontological Statics), version 1.98 (1999 - 2010) (Hammer et al., 2001).

The frequency of occurrence (FO) and the species dominance were calculated for each bee species obtained. Frequency of occurrence is the percentage of the number of collections with a given species and was calculated as $\mathrm{FO}=(\mathrm{F} / \mathrm{N}) \times 100$ (Silveira Neto et al., 1976), where "F" is the number of collections with the species and " $\mathrm{N}$ " is the total number of collections performed. The bee species were classified as primary (FO $>50 \%)$, secondary $(\mathrm{FO}=25 \%$ $50 \%)$, or accidental $(\mathrm{FO}<25 \%)$.

The species dominance of bees (D) was calculated as $D=(d / n) \times 100$ (Palma, 1975), where " $d$ " is the abundance of a specific species and " $\mathrm{n}$ " the total abundance. The species were classified as dominant ( $\mathrm{D}>5 \%$ ), accessory $(\mathrm{D}=2.5 \%-5 \%$ ), or accidental ( $\mathrm{D}<2.5 \%)$. According to Palma (1975), the FO and $\mathrm{D}$ indices when used together group and determine the species as common, intermediary or rare. 


\section{Results}

The flowering occurred from August 25 to September 14, 2012. During this period, 17 collections were performed for a total of 168 hours. Due to the similarity of the collection areas the bees obtained at both locations were grouped in only one sample.

A total of 826 bees belonging to 39 species and the four subfamilies Andreninae, Colletinae, Apinae and Halictinae were captured. The most abundant species was Apis mellifera
(337 individuals), followed by Scaptotrigona bipunctata (293) and Melipona obscurior (74). Fifteen species were recorded by one specimen only (Table 1). The subfamily with the highest number of species was Halictinae (23 species); Andreninae was represented by just one species (Anthrenoides paolae). The bees were captured from 9:00 to 16:30, with highest numbers collected in the intervals between 10:00 and 10:30, and 11:00 and 11:30 and with highest number of species in the interval from $11 \mathrm{~h}$ to $11: 30$ (Table 2).

Table 1 - Species of flower visiting bees collected on Eugenia uniflora L. in fragments of mixed ombrophilous forest (Atlantic Forest) in south Brazil. Indices of frequency of occurrence (FO), dominance (D) and the denomination for each species of floral visitor bee.

\begin{tabular}{|c|c|c|c|c|c|c|}
\hline Subfamily & Tribe & Genus/species & $\begin{array}{l}\text { Number of } \\
\text { Individuals }\end{array}$ & FO (\%) & $\mathrm{D}(\%)$ & Denomination \\
\hline Andreninae & Protandrenini & Anthrenoides paolae Urban, 2005 & 15 & 47.05 & 1.82 & Intermediary \\
\hline \multirow[t]{4}{*}{ Colletinae } & Hylaeini & Hylaeus aff. geminus (Vachal, 1910) & 1 & 5.8 & 0.12 & Rare \\
\hline & Hylaeini & Hylaeus aff. vachali Meade-Waldo, 1923 & 3 & 17.64 & 0.36 & Rare \\
\hline & Hylaeini & Hylaeus cf. asper (Vachal, 1909) & 1 & 5.8 & 0.12 & Rare \\
\hline & Colletini & Rhynchocolletes albicinctus Moure, 1943 & 1 & 5.8 & 0.12 & Rare \\
\hline \multirow[t]{23}{*}{ Halictinae } & Augochlorini & Augochlora sp. Smith, 1853 & 5 & 29.42 & 0.61 & Rare \\
\hline & Augochlorini & Augochloropsis cf. cognata Moure, 1944 & 6 & 29.41 & 0.73 & Intermediary \\
\hline & Augochlorini & Augochloropsis chloera (Moure, 1940) & 1 & 5.8 & 0.12 & Rare \\
\hline & Augochlorini & Augochloropsis cupreola (Cockerell, 1900) & 2 & 11.76 & 0.24 & Rare \\
\hline & Augochlorini & Augochloropsis imperialis (Vachal, 1903) & 5 & 23.52 & 0.61 & Rare \\
\hline & Augochlorini & Augochloropsis notophos (Vachal, 1903) & 3 & 17.64 & 0.36 & Rare \\
\hline & Augochlorini & Augochloropsis sparsilis (Vachal, 1903) & 1 & 5.8 & 0.12 & Rare \\
\hline & Augochlorini & Augochloropsis sympleres (Vachal, 1903) & 3 & 17.64 & 0.36 & Rare \\
\hline & Augochlorini & Ceratalictus psoraspis (Vachal, 1911) & 1 & 5.8 & 0.12 & Rare \\
\hline & Augochlorini & Halictillus loureiroi (Moure, 1941) & 3 & 11.76 & 0.36 & Rare \\
\hline & Augochlorini & Neocorynura cf. chapadicola (Cockerell, 1901) & 2 & 5.8 & 0.24 & Rare \\
\hline & Augochlorini & Paroxystoglossa andromache (Schrottky, 1909) & 2 & 11.76 & 0.24 & Rare \\
\hline & Augochlorini & Paroxystoglossa cf. barbata Moure, 1960 & 1 & 5.8 & 0.12 & Rare \\
\hline & Augochlorini & Paroxystoglossa sp. Moure, 1941 & 4 & 17.64 & 0.48 & Rare \\
\hline & $\begin{array}{l}\text { Halictini } \\
\text { (Caenohalictina) }\end{array}$ & Caenohalictus tesselattus (Moure, 1940) & 1 & 5.8 & 0.12 & Rare \\
\hline & Halictini (Halictina) & Dialictus bruneriellus (Cockerell, 1918) & 2 & 11.76 & 0.24 & Rare \\
\hline & Halictini (Halictina) & Dialictus pabulator (Schrottky, 1910) & 1 & 5.8 & 0.12 & Rare \\
\hline & Halictini (Halictina) & Dialictus picadensis (Strand, 1910) & 2 & 11.76 & 0.24 & Rare \\
\hline & Halictini (Halictina) & Dialictus sp.1Robertson, 1902 & 1 & 5.8 & 0.12 & Rare \\
\hline & Halictini (Halictina) & Dialictus sp.2 Robertson, 1902 & 2 & 11.76 & 0.24 & Rare \\
\hline & Halictini (Halictina) & Dialictus sp.3 Robertson, 1902 & 1 & 5.8 & 0.12 & Rare \\
\hline & Halictini (Halictina) & Dialictus sp.4 Robertson, 1902 & 1 & 5.8 & 0.12 & Rare \\
\hline & Halictini (Halictina) & Dialictus sp.5Robertson, 1902 & 1 & 5.8 & 0.12 & Rare \\
\hline
\end{tabular}


Table 1. Species of flower visiting bees collected on Eugenia uniflora L. in fragments of mixed ombrophilous forest (Atlantic Forest) in south Brazil. Indices of frequency of occurrence (FO), dominance (D) and the denomination for each species of floral visitor bee. (Continuation)

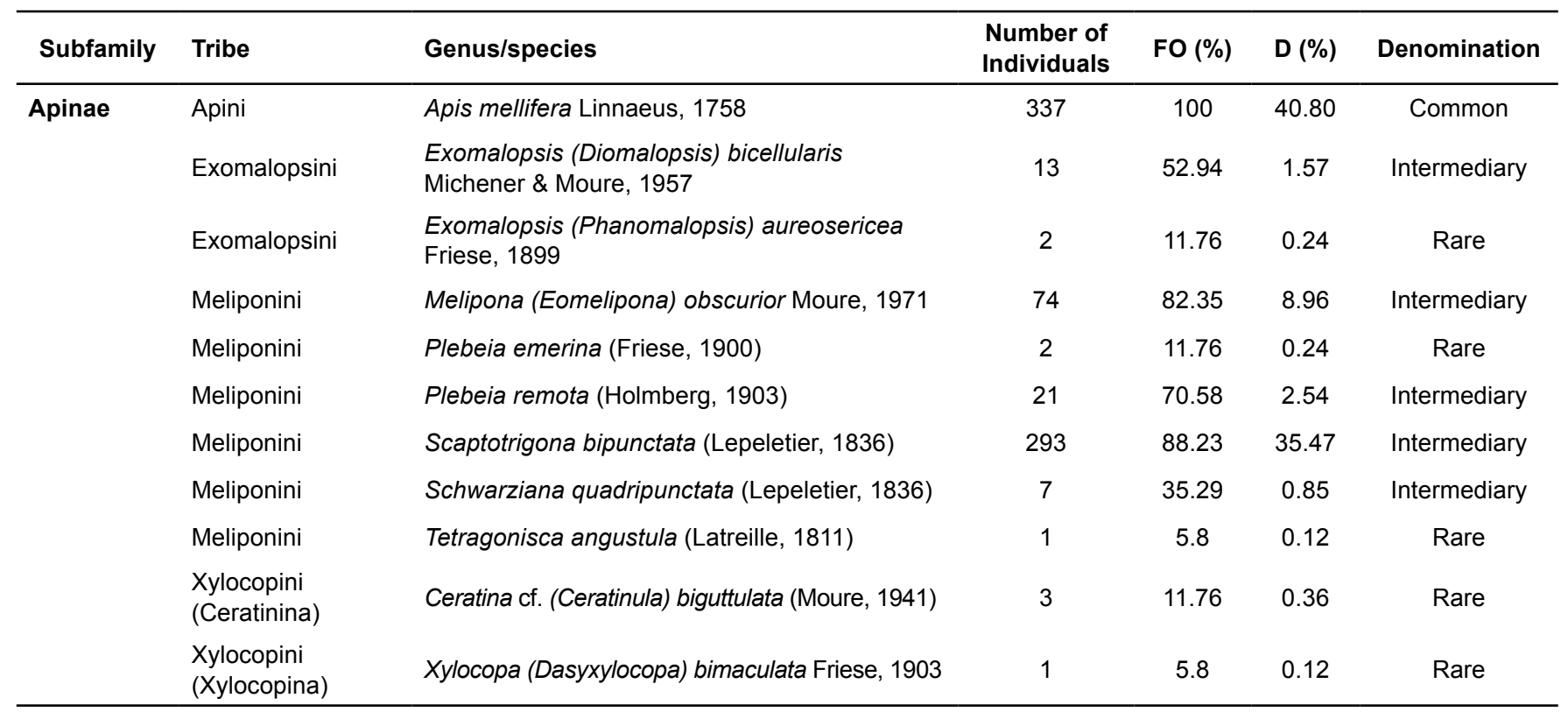

The Margalef Richness Index (Dmg) for the bee sample collected in this study was 5.658, and the Shannon-Wiener Diversity Index (H') was 1.686.The Pielou Evenness Index (J) was 0.4601 .

The obtained FO and Dvalues classified only A. mellifera as common visitors of $E$. uniflora flowers. Seven species were classified as intermediary: M. obscurior, S. bipunctata, A. paolae, Schwarziana quadripunctata, Exomalopsis bicellularis, Plebeia remota and Augochloropsis cf. cognata.The other 31 bee species were considered rare visitors of E. uniflora (Table 1).

\section{Discussion}

The richness and diversity of bee visitors of E. uniflora was much higher than the 11 species recorded by Silva and Pinheiro (2007) in the western part of the municipality of Rio de Janeiro (Rio de Janeiro state, Brazil).High values of richness and diversity indicate, in most cases, a well-structured community, with many rare species (Costa et al., 1993). According to Michener (1979), southern Brazil it is one of the regions in the world with the highest richness of Apoidea. Regarding the species richness per subfamilies, our sample from the Guarapuava (PR) region also had a higher numbers of species of Apinae visiting E. uniflora flowers than recorded in Rio de Janeiro state, but we must consider that both studies were conducted in totally different phytophysionomies.

The greatest activity of bees on E. uniflora flowers occurred during the hottest hours of the day. Bees' foraging activity is influenced by weather conditions, mainly temperature because maintaining high body temperature during the flight is energetically costly (Roubik, 1989).

Flower visitors of the subfamilies Colletinae and Andreninae are new records for E. uniflora.In the southern region of Brazil, the most diverse subfamilies are Apinae and Halictinae (Alves-dos-Santos, 2007), and we also found the greatest number of speciesfor Halictinae among the flower visitors or E. uniflora, demonstrating that this pattern is also reflected in our bee sample.

Silva and Pinheiro (2007) considered species of the genus Xylocopa to be among the pollinators of E. uniflora. It is therefore possible that $X$. bimaculata, even though it was a rare visitor, is also able to pollinate those flowers. Bees of the genus Xylocopa are also floral visitors of other Myrtaceae species (Schlindwein et al., 2003; Siqueira et al., 2012).

Out of all the species captured in this study, only A. mellifera was classified as common, which was also observed in E. uniflora flowers by both Pelacani et al. (2000) in São Paulo state (Brazil), and by Silva and Pinheiro (2007). Although A. mellifera is an exotic species in Brazil, it has become the most common floral visitor in the Neotropics (Roubik, 2000). Apis mellifera has considerable interference in the reproduction of many plant species and can facilitate or hamper their reproductive success, influencing directly or indirectly on the foraging of native pollinators (Paton, 1993; Vaughton, 1996; Villanueva-G, 2002). According to Silva and Pinheiro (2007) the high number of A. mellifera in the early anthesis can impair the pollen supply for native visitors. This may be one of the reasons for the high number of species considered rare visitors of E. uniflora, because there is a lower amount of pollen available when native bees start the foraging. Depletion of pollen is also indicated by the sharp decrease in the number of pollinators after 12:30 h.

Of the species belonging to the genus Scaptotrigona only S. xanthotricha Moure, 1950 was registered visiting $E$. uniflora flowers in Rio de Janeiro state (Silva \& Pinheiro, 2007). Other species, namely S. depilis (Moure, 1942) and 
Table 2. Dial pattern of the number of flower visiting bees captured on Eugenia uniflora L., in fragments of mixed ombrophilous forest.

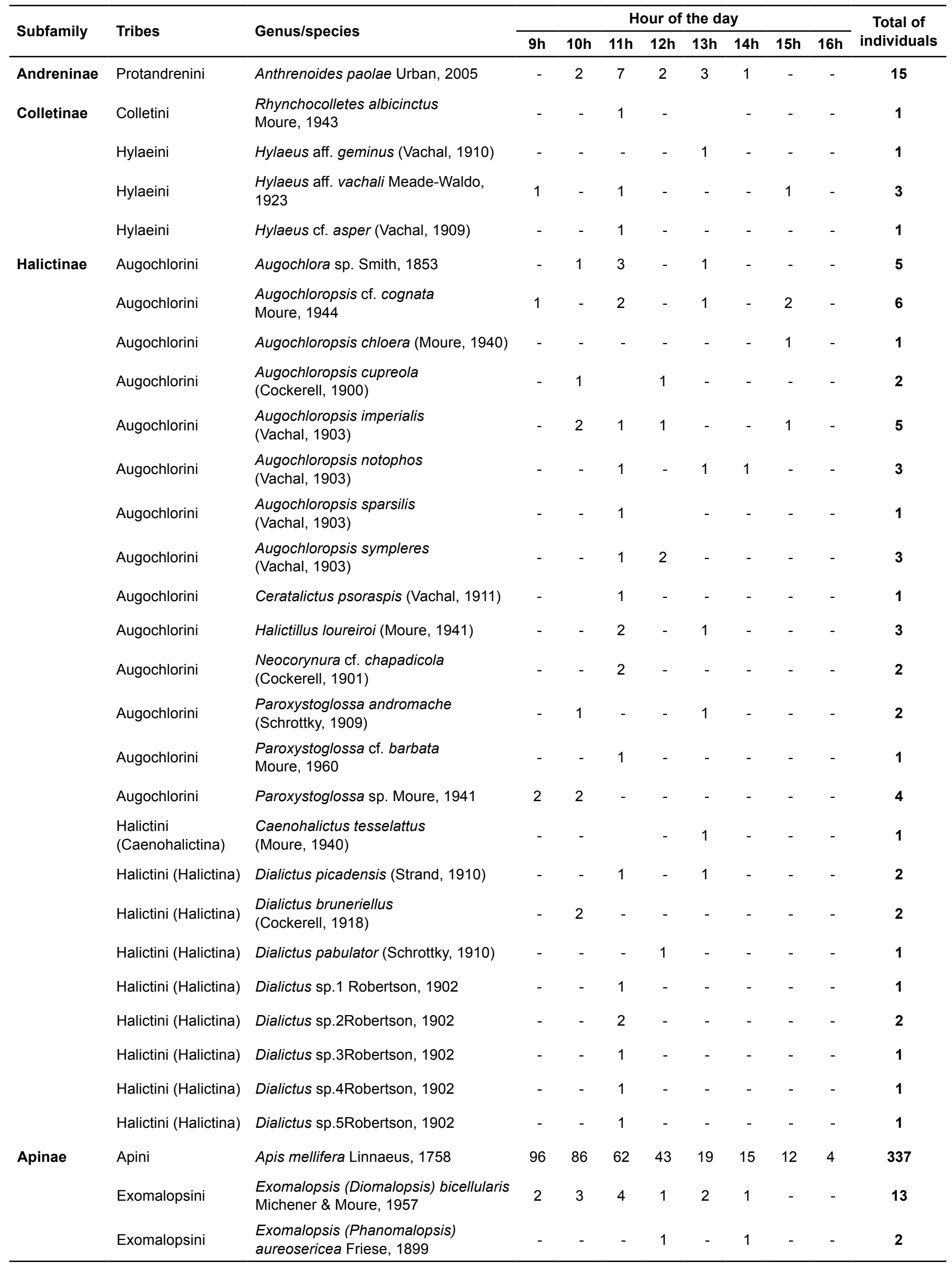


Table 2. Dial pattern of the number of flower visiting bees captured on Eugenia uniflora L.,in fragments of mixed ombrophilous forest. (Cont.)

\begin{tabular}{|c|c|c|c|c|c|c|c|c|c|c|c|}
\hline \multirow{2}{*}{ Subfamily } & \multirow{2}{*}{ Tribes } & \multirow{2}{*}{ Genus/species } & \multicolumn{8}{|c|}{ Hour of the day } & \multirow{2}{*}{$\begin{array}{l}\text { Total of } \\
\text { individuals }\end{array}$} \\
\hline & & & $9 \mathrm{~h}$ & $10 \mathrm{~h}$ & $11 \mathrm{~h}$ & $12 \mathrm{~h}$ & $13 \mathrm{~h}$ & $14 \mathrm{~h}$ & $15 \mathrm{~h}$ & $16 \mathrm{~h}$ & \\
\hline \multirow[t]{10}{*}{ Apinae } & Meliponini & $\begin{array}{l}\text { Melipona (Eomelipona) obscurior } \\
\text { Moure, } 1971\end{array}$ & 2 & 13 & 18 & 17 & 14 & 9 & 1 & - & 74 \\
\hline & Meliponini & Plebeia emerina (Friese, 1900) & - & - & 1 & 1 & - & - & - & - & 2 \\
\hline & Meliponini & Plebeia remota (Holmberg, 1903) & 2 & 2 & 3 & 7 & 5 & 1 & 1 & - & 21 \\
\hline & Meliponini & $\begin{array}{l}\text { Scaptotrigona bipunctata } \\
\text { (Lepeletier, 1836) }\end{array}$ & 44 & 91 & 85 & 46 & 19 & 7 & 1 & - & 293 \\
\hline & Meliponini & $\begin{array}{l}\text { Schwarziana quadripunctata } \\
\text { (Lepeletier, 1836) }\end{array}$ & 1 & 2 & 3 & 1 & - & - & - & - & 7 \\
\hline & Meliponini & $\begin{array}{l}\text { Tetragonisca angustula } \\
\text { (Latreille, 1811) }\end{array}$ & - & - & - & - & 1 & - & - & - & 1 \\
\hline & $\begin{array}{l}\text { Xylocopini } \\
\text { (Ceratinina) }\end{array}$ & $\begin{array}{l}\text { Ceratina cf. (Ceratinula) biguttulata } \\
\text { (Moure, 1941) }\end{array}$ & - & - & - & 2 & 1 & - & - & - & 3 \\
\hline & $\begin{array}{l}\text { Xylocopini } \\
\text { (Xylocopina) }\end{array}$ & $\begin{array}{l}\text { Xylocopa (Dasyxylocopa) bimaculata } \\
\text { Friese, } 1903\end{array}$ & 1 & - & - & - & - & - & - & - & 1 \\
\hline & \multicolumn{2}{|c|}{ Total No of specimens } & 152 & 208 & 208 & 126 & 72 & 36 & 20 & 4 & 826 \\
\hline & \multicolumn{2}{|c|}{ Total No of species } & 10 & 13 & 27 & 14 & 16 & 8 & 8 & 1 & - \\
\hline
\end{tabular}

S. fulvicutis (Moure, 1964) were found as abundantflower visitors of Myrtaceae in Mato Grosso do Sul and Amazonas states in Brazil (Marques-Souza et al., 2007; Ferreira et al., 2010). Scaptotrigona bipunctata is among the most common species of Meliponini found in Paraná state (Paraná, 2009), which explains the large number of individuals collected in this work. This species displays highly defensive behaviour (Nogueira-Neto, 1970), which could explainits abundance and its frequency found here, when compared to the presence of other species.

Melipona obscurior bees are polylectic foragers (KleinertGiovannini \& Imperatriz Fonseca, 1987) and there are records of their occurrence in Bahia state, as well as in southern and southwestern Brazil (Roubik, 1989; Nogueira-Neto, 1997; Silveira et al., 2002). Bees in this genus (Melipona scutellaris Latreille, 1811) were reported to pollinate Psidium guajava L. (Myrtaceae) (Castro \& Araújo, 1998).

The findings that deserve highlighting in this work is the unprecedented recording of Plebeia remota in E. uniflora flowers. Plebeia remota is not commonly observed as a floral visitor or pollinator of other Myrtaceae species. Another unprecedented record was the presence of $A$. paolae visiting E. uniflora flowers, given that no floral visitation or pollination of this species to any Myrtaceae has been observed before.

Apis mellifera is possibly the most important potential pollinator of E. uniflora because it was the most frequent floral visitor, followed by S. bipunctata and M. obscurior. This study reveals that E. uniflora is an easily obtainable pollen source for exotic and native bees, and thus contributes to the conservation of these bee species in forest fragments helping in the maintaining the biodiversity of the bees in these fragments. At the same time, these bees are probably acting in the preservation of this native plant and assist in the regeneration of the highly fragmented Atlantic Forest.

\section{Acknowledgments}

We thank CAPES (Coordenação de Aperfeiçoamento de Pessoal de Nível Superior) for the scholarship and the Programa de Pós-Graduação em Biologia Evolutiva of Universidade Estadual do Centro-Oeste (UNICENTRO). We also thank Gabriel A. R. Melo of Universidade Federal do Paraná (UFPR) for bee identification and Cláudia I. Silva for the help with sample design.

\section{References}

Aguiar, R.V., Cansian, R.L., Kubiak, G.B., Slaviero, L.B., Tomazoni, T.A., Budke, J.C., Mossi, A.J.(2013). Variabilidade genética de Eugenia uniflora L. em remanescentes florestais em diferentes estádios sucessionais. Ceres, 60: 226-233

Alves-dos-Santos, I. (2007) Estudos sobre comunidades de abelhas no Sul do Brasil e proposta para avaliação rápida da apifauna subtropical. Revista Brasileira de Ecologia, 11: 53-65

Beardsell, D.V., O’Brie,n S.P., Williams, E.G., Knox, R.B., Calder D.M. (1993). Reproductive biology of Australian Myrtaceae. Australian Journal of Botany, 41: 511-526

Bosch, J., González, A.M.M., Rodrigo, A., Navarro, D. (2009). Plant pollinator networks: adding the pollinator's perspective. Ecology Letters, 12: 409-419. doi: 10.1111/j.14610248.2009.01296.x.

Brown, M.J.F., Paxton, R.J. (2009). The conservation of bees: a global perspective. Apidologie, 40: 410-416. doi: 10.1051/ apido/2009019

Callegaro, R.M., Longhi, S.J., Biali, L.J., Ebling, A.A., Andrzejewski, C., Brandão, C.F.L.S. (2012). Regeneração 
natural avançada de um fragmento de mata ciliar em Jaguari, RS, Brasil. Revista Brasileira de Ciências Agrárias, 7: 315-321

Castro, M.S., Araujo, V.M.L. (1998). Visita de abelhas às flores da goiabeira (Psidium guajava L.). http://www.seb-ecologia. org.br/viiceb/resumos/790a.pdf. (Acessed: 23 September, 2015).

Conservation International do Brasil, Fundação Biodiversitas, Instituto de Pesquisas Ecológicas, Secretaria do Meio Ambiente do Estado de São Paulo, Semad/Instituto Estadual de Florestas MG (2000). Avaliação e ações prioritárias para a conservação da biodiversidade da Floresta Atlântica e Campos Sulinos. MMA/SBF, Brasília.http://www.rbma.org.br/anuario/pdf/areas prioritarias.pdf. (Acessed 22 September, 2015)

Costa, E.C., Link, D., Medina, L.D. (1993). Índice de diversidade para entomofauna da Bracatinga (Mimosa scabrella Benth.) Ciência Florestal, 3: 65- 75

Dafni, A., Kevan, P.G., Husband, B.C. (2005). Practical pollination biology. Cambridge: Enviroquest, Ontario

Endress, P.K.(1994). Diversity and evolutionary biology of tropical flowers. Cambridge University Press

Faegri, K., Van Der Pijl, L. (1979). The principles of pollination ecology. Pergamon Press, Oxford, 244p

Falconer, D.S., Mackay, T.F. (1996). Introdução à genética quantitativa. Londres, Longman

Ferreira, M.G., Manente-Balestieri, F.C.D., Balestieri, J.B.P. (2010). Pollen harvest by Scaptotrigona depilis (Moure) (Hymenoptera, Meliponini) in Dourados, Mato Grosso do Sul, Brazil. Revista Brasileira de Entomologia, 54: 258-262

Franzon, R.C., Castro, C.M., Raseira, M.C.B. (2010). Variabilidade genética em populações de pitangueira oriundas de autopolinização e polinização livre, acessada por AFLP. Revista Brasileira de Fruticultura, 32: 240-250.

Franzon, R.C., Castro, C.M., Raseira, M.C.B. (2011). Marcadores AFLP no Estudo da Variabilidade Genética de Populações de Pitangueira (Eugenia uniflora L.). Embrapa Clima Temperado. Boletim de Pesquisa e Desenvolvimento, 151

Gentry, A.H. (1974). Flowering phenology and diversity in tropical Bignoniaceae. Biotropica, 6: 64-68

Grant, V. (1971). Plant Speciation. Columbia University Press, Columbia, New York.

Gressler, E., Pizo, M.A., Morellato, L.P.C. (2006). Polinização e dispersão de sementes em Myrtaceae do Brasil. Revista Brasileira de Botânica, 29: 509- 530

Hagen, M., Kissling, W.D. et al. (2012). Biodiversity, Species Interactions and Ecological Networks in a Fragmented World. http://ecologia.ib.usp.br/guimaraes/papers/hagen.pdf. (Acessed: 23 September, 2015).

Hammer, Ø., Harper, D.A.T., Ryan, P.D. (2001). PAST: Paleontological statistics software package for education and data analysis. Palaeontologia Electronica. http://palaeoelectronica.org/2001_1/past/issue1_01.htm. (Accessed: 01 December, 2013).

Johnson, L.A.S., Briggs, B.G. (1984). Myrtales and Myrtaceae - A phylogenetic approach. Annals of the Missouri Botanical Garden, 71: 700-756.

Kawasaki, M.L., Landrum, L.R. (1997). A rare and potentially economic fruit of Brazil - cambuci, Campomanesia phaea (Myrtaceae). Economic Botany, 51: 403-407

Keller, L.F., Waller, D.M. (2002). Inbreeding effects in wild population. Trends in Ecology and Evolution, 17: 230-241.

Kevan, P.G., Phillips, T.P. (2001). The economic impacts of pollinator declines: an approach to assessing the consequences. Conservation Ecology, 5: 8

Kleinert-Giovannini, A., Imperatriz-Fonseca, V.L. (1987). Aspects of the trophic niche of Melipona marginata marginata Lepeletier (Apidae, Meliponinae). Apidologie, 18: 69-100

Kremen, C., Williams, N.M., Thorp, R.W. (2002). Crop pollination from native bees at risk from agricultural intensification. Proceedings of the National Academy of Sciences USA, 99 (26) $p$

Laroca, S., Cure, J.R., Bortoli, C. (1982). A associação de abelhas silvestres (Hymenoptera, Apoidea) de uma área restrita no interior da cidade de Curitiba (Brasil): uma abordagem biocenótica. Dusenia, 13 (3) : 93-117

Lorenzi,H. (2000). Árvores Brasileiras: Manual de Identificação e Cultivo de Plantas Arbóreas do Brasil. Nova Odessa - SP: Instituto Plantarum de Estudos de Flora LTDA.

Lorenzi, H. (2002). Árvores Brasileiras: Manual de identificação e cultivo de plantas arbóreas do Brasil. Nova Odessa, SP: Instituto Plantarum, 368p

Lughadha, E.N., Proença, C. (1996). A survey of the reproductive biology of the Myrtoideae (Myrtaceae). Annals of the Missouri Botanical Garden, 83: 480-503

Maack, R. (1981). Geografia física do Estado do Paraná. Rio de Janeiro, 442p

Marques-Souza, A.C., Absy, M.L., Kerr, W.E. (2007). Pollen harvest features of the Central Amazonian bee Scaptotrigona fulvicutis Moure 1964 (Apidae: Meliponinae), in Brazil. Acta Botanica Brasilica, 21: 11-20.

Maués, M.M., Couturier, G. (2002). Biologia floral e fenologia reprodutiva de camucamu (Myrciaria dubia (H.B.K.) McVaugh, Myrtaceae) no Estado do Pará, Brasil. Revista Brasileira de Botânica, 25: 441-448

Mazine, F.F., Faria, J.E.Q. (2013). A new species of Eugenia (Myrtaceae) from South America. Phytotaxa, 151: 53-57.

Merwe, M.M., Wyk, A.E., Botha, A.M. (2004). Molecular phylogenetic analysis of Eugenia L. (Myrtaceae), with emphasis 
on southern Africa taxa. Plant Systematic and Evolution, 251: 21-34. doi: 10.1007/s00606-004-0160-0

Mettler, L.E., Gregg, T.G. (1973). Genética de populações e evolução. São Paulo, Polígono/EDUSP, 262p

Michener, C.D. (1979). Biogeography of the bees. Annals of the Missouri Botanical Garden, 66: 277-347.

Myers, N., Mittermeier, R.A., Mittermeier, C.G., Fonseca, G.A.B., Kent, J. (2000). Biodiversity hotspots for conservation priorities. Nature, 403: 853-858.

Nogueira-Neto, P. (1970). A criação de abelhas indígenas sem ferrão. Tecnapis, São Paulo

Nogueira-Neto, P. (1997). Vida e criação de abelhas indígenas sem ferrão. Nogueirapis, São Paulo

O'Brien, S.P., Calder, D.M. (1993). Reproductive biology and floral phenologies of the sympatric species Leptospermum myrsinoides and L. continentale (Myrtaceae). Australian Journal of Botany, 41: 527-539

Palma, S. (1975). Contribución al studio de los sifonoforos encontrados frente a la costa de Valparaiso. Aspectos ecológicos. II Simpósio Latino Americano Sobre Oceanografia Biológica. Dóriente, Venezuela, 119-133

Paraná, Instituto Ambiental do. (2009), Plano de Conservação para Abelhas Sociais Nativas sem ferrão. IAP/ Projeto Paraná Biodiversidade. http://www.redeprofauna.pr.gov.br/arquivos/ File/Abelhasweb.pdf. (Accessed: 22 September, 2015).

Paton, D.C. (1993). Honeybees in the australian environment. Does Apis mellifera disrupt or benefit the native biota? Bioscience, 43: 95-103

Pedro, S.E.M., Camargo, J.M.F. (2000). Apoidea Apiformes, In Biodiversidade do Estado de São Paulo, Brasil. Invertebrados Terrestres. Fapesp, 5: 195-211.

Pelacani, M.G.N., Jesus, A.R.G., Spina, S.M., Figueiredo, R.A. (2000). Biologia floral da pitangueira (Eugenia uniflora L., Myrtaceae). Revista Argumento, 4: 17-20

Pinheiro-Machado, C., Silveira, F.A. (2006). Surveying and monitoring of pollinators in natural landscapes and in cultivated fields In Fonseca VLI, Saraiva AM, Jong DD Bees as pollinators in Brazil: Assessing thestatus and suggesting best practices. Holos, Ribeirão Preto, 96p

Primack, R.B., Rodrigues, E. (2001). Biologia da Conservação. Londrina, 327p

Potts, S.G., Biesmeijer, J.C., Kremen, C., Neumann, P., Schweiger, O., Kunin, W.E. (2010). Global pollinator declines: trends, impacts and drivers. Trends in Ecology and Evolution, 25: $345-353$

Proença, C., Gibbs, P.E. (1994). Reproductive biology of eight sympatric Mirtaceae from Central Brazil. New Phytologisty, 126: 343-354.
Ramirez, N., Brito, Y. (1992) Pollination biology in a palm swamp community in the Venezolana central plains. Botanical Journal of the Linnean Society, 110: 277-302

Romagnolo, M.B., Sousa, C.O.M. (2006). O gênero Eugenia L. (Myrtaceae) na planície alagável do Alto Rio Paraná, Estados de Mato Grosso do Sul e Paraná, Brasil. Acta Botanica Brasilica, 20: 529-548

Roubik, D.W. (1989). Ecology and natural history of tropical bees. Cambridge Tropical Biology Series, Cambridge, 514p

Roubik, D.W. (2000). The foraging and potential outcrossing pollination ranges of African honey bees (Apiformes: Apidae; Apini) in Congo forest. Journal of the Kansas Entomological Society, 72: 394-401.

Scalon, S.P.Q., Scalon Filho, H., Rigoni, M.R., Veraldo, F. (2001). Germinação e crescimento de mudas de pitangueira (Eugenia uniflora L.) sob condições de sombreamento. Revista Brasileira de Fruticultura, 23: 652-655.

Schlindwein, C., Schlumpberger, B., Wittmann, D., Moure, J.S.O. (2003). Gênero Xylocopa Latreille no Rio Grande do Sul, Brasil (Hymenoptera, Anthophoridae). Revista Brasileira de Entomologia, 47: 107-118.

Silva, A.L.G., Pinheiro, M.C.B. (2007). Biologia floral e da polinização de quatro espécies de Eugenia L. (Myrtaceae) Acta Botanica Brasiliensis, 21: 235-247.

Silva, R.S.M., Chaves, L.J., Naves, R.V. (2001)Caracterização de frutos e árvores de cagaita (Eugenia dysenterica DC.) no sudeste do Estado de Goiás, Brasil. Revista Brasileira de Fruticultura, 23: 330-334

Silveira, F.A., Melo, G.A.R., Almeida, E.A.B. (2002). Abelhas brasileiras: sistemática e identificação. IDMAR, Belo Horizonte, 253p

Silveira Neto, S., Nakano, O., Barbin, D., Villa Nova, N.A. (1976). Manual de ecologia dos insetos. Ceres, Piracicaba, 419p

Siqueira, K.M.M., Kiill, L.H.P., Martins, C.F., Silva, L.T. (2012). Ecologia da polinização de Psidium guajava L. (Myrtaceae): riqueza, frequência e horário de atividades de visitantes florais em um sistema agrícola. Magistra, 24: 150-157

Sobral, M., Proença, C., Souza, M., Mazine, F.F., Lucas, E. (2015). Myrtaceae. In: Lista de Espécies da Flora do Brasil. http://floradobrasil.jbrj.gov.br. (Acessed: 22 September, 2015).

Souza, M.A.D., Scudeller, V.V., Mendonça, M.S. (2015). Three new species of Eugenia (Myrtaceae) from Brazilian Amazonia. Phytotaxa, 212: 87-94.

Stebbins, G.L. (1950). Variation and Evolution in Plants. Columbia University Press, Columbia

Steffan-Dewenter, I., Klein, A.M., Gaebele, V., Alfert, T., Tscharntke, T. (2006). Bee Diversity and Plant-Pollinator Interactions in Fragmented Landscapes. In: Wasser NM , 
Ollerton J. Plant Pollinator interaction from specialization to generalization. The University of Chicago Press: $387-407,488$ p

Vaughton, G. (1996). Pollination disruption by European honeybees in the Australian bird-pollinated shrub Grevillea barklyna (Proteaceae). Plant Systematic and Evolution, 200: 89-100.
Villanueva-G., R. (2002). Polliniferous plants and foraging strategies of Apis mellifera (Hymenoptera: Apidae) in the Yacatán Peninsula, México. Revista de Biologia Tropical, 50: 1035-1044.

Wilson, G.W., O’Brien, M.M., Gadek, P.A., Quinn, C.J. (2001). Myrtaceae revisited: A reassessment of intrafamilial groups. American Journal of Botany, 88: 2013-2025.

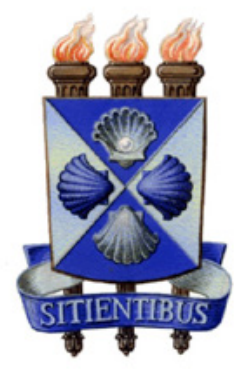

